\title{
Vanadium oxide monolayer catalysts. 3. A Raman spectroscopic and temperature-programmed reduction study of monolayer and crystal-type vanadia on various supports
}

\author{
Citation for published version (APA): \\ Roozeboom, F., Mittelmeijer-Hazeleger, M. C., Moulijn, J. A., Medema, J., Beer, de, V. H. J., \& Gellings, P. J. \\ (1980). Vanadium oxide monolayer catalysts. 3. A Raman spectroscopic and temperature-programmed \\ reduction study of monolayer and crystal-type vanadia on various supports. Journal of Physical Chemistry, \\ 84(21), 2783-2791. https://doi.org/10.1021/j100458a023
}

DOI:

10.1021/j100458a023

Document status and date:

Published: 01/01/1980

\section{Document Version:}

Publisher's PDF, also known as Version of Record (includes final page, issue and volume numbers)

\section{Please check the document version of this publication:}

- A submitted manuscript is the version of the article upon submission and before peer-review. There can be important differences between the submitted version and the official published version of record. People interested in the research are advised to contact the author for the final version of the publication, or visit the DOI to the publisher's website.

- The final author version and the galley proof are versions of the publication after peer review.

- The final published version features the final layout of the paper including the volume, issue and page numbers.

Link to publication

\footnotetext{
General rights

- You may freely distribute the URL identifying the publication in the public portal. follow below link for the End User Agreement:

www.tue.nl/taverne

\section{Take down policy}

If you believe that this document breaches copyright please contact us at:

openaccess@tue.nl

providing details and we will investigate your claim.
}

Copyright and moral rights for the publications made accessible in the public portal are retained by the authors and/or other copyright owners and it is a condition of accessing publications that users recognise and abide by the legal requirements associated with these rights.

- Users may download and print one copy of any publication from the public portal for the purpose of private study or research.

- You may not further distribute the material or use it for any profit-making activity or commercial gain

If the publication is distributed under the terms of Article $25 \mathrm{fa}$ of the Dutch Copyright Act, indicated by the "Taverne" license above, please 


\title{
Vanadlum Oxide Monolayer Catalysts. 3. A Raman Spectroscoplc and Temperature-Programmed Reduction Study of Monolayer and Crystal-Type Vanadia on Varlous Supports ${ }^{1,2}$
}

\author{
F. Roozeboom, * M. C. Mittelmeijer-Hazeleger, ${ }^{\dagger}$ J. A. Moulljn, ${ }^{\dagger}$ J. Medema, ${ }^{\ddagger}$ V. H. J. de Beer, ${ }^{\$}$ \\ and P. J. Gellings
}

Department of Chemical Engineering, Twente Universtly of Technology, 7500 AE Enschede, The Netherlands (Rocelved: March 25, 1980)

\begin{abstract}
Vanadium (V) oxide supported on $\gamma-\mathrm{Al}_{2} \mathrm{O}_{3}, \mathrm{CeO}_{2}, \mathrm{Cr}_{2} \mathrm{O}_{3}, \mathrm{SiO}_{2}, \mathrm{TiO}_{2}$, and $\mathrm{ZrO}_{2}$ was studied by $\mathrm{X}$-ray fluorescence, by $\mathrm{X}$-ray diffraction, and especially by the combination of Raman spectroscopy and temperature-programmed reduction (TPR) for qualitative and quantitative structural analysis, respectively. Catalysts were prepared via ion-exchange and wet-impregnation methods. The V contents ranged from $\sim 1$ to 40 wt $\% \mathrm{~V}$. At low surface concentrations only surface vanadate phases of two-dimensional character are observed for all carriers. According to Raman and TPR data the structure of these surface vanadate species is independent of the preparation technique. At medium and high surface concentrations, the wet-impregnated samples already contain crystalline $\mathrm{V}_{2} \mathrm{O}_{5}$. At equal surface concentrations the ion-exchanged catalysts contain no $\mathrm{V}_{2} \mathrm{O}_{5}$ crystallites. An exception is $\mathrm{SiO}_{2}$ on which also crystalline $\mathrm{V}_{2} \mathrm{O}_{5}$ is formed in both preparation techniques. Monolayer stability toward thermal treatment decreases in the order $\mathrm{Al}_{2} \mathrm{O}_{3}>\mathrm{TiO}_{2}>\mathrm{CeO}_{2}$, whereas on heating ion-exchanged $\mathrm{V} / \mathrm{SiO} \mathrm{O}_{2}$ the crystalline $\mathrm{V}_{2} \mathrm{O}_{5}$ spreads out over the silica surface. The reducibilities of the ion-exchanged catalysts, as measured by TPR, can be used as a measure for the contact interaction between vanadia and the carrier oxides. At temperatures of $500-800 \mathrm{~K}$, this interaction ranges from strong with titania to weak with silica as a carrier.
\end{abstract}

\section{Introduction}

Vanadium oxides are widely used as catalysts in oxidation reactions, e.g., the oxidation of sulfur dioxide, carbon monoxide, and hydrocarbons. ${ }^{3,4}$ When supported mostly oxidic supports are used.

The existence of different surface vanadium oxides on various supports has been the subject of several studies. ${ }^{1,2,5-14}$ In general the influence of parameters such as the method of preparation, the nature of the support, the concentration of active component, and the thermal treatment on the structure of the catalyst and its catalytic behavior has been studied.

Recent publications show that Raman spectroscopy is a valuable technique in catalytic research. It was used by, among others, Brown et al., ${ }^{15}$ Medema et al., ${ }^{16}$ and Knözinger and Jeziorowski ${ }^{17,18}$ in the identification of supported molybdenum oxide species, whereas tungsten oxide supported on silica or alumina was studied by Thomas et al. ${ }^{19,20}$ In a previous paper ${ }^{2}$ on vanadium oxide $/ \gamma \cdot \mathrm{Al}_{2} \mathrm{O}_{3}$, it was shown, however, that Raman spectroscopy cannot be used for quantitative determination of the different surface and bulk phases: $\mathrm{V}_{2} \mathrm{O}_{5}$ crystallites are considerably more Raman active than the surface phases, whereas the surface phases themselves may also differ in Raman activity. Similar results were reported for supported molybdenum ${ }^{19}$ and tungsten ${ }^{21}$ oxide catalysts.

With respect to quantitative analysis, temperatureprogrammed reduction (TPR) has proved to be a more appropriate tool. ${ }^{22-25}$ Moreover this technique gives information about the reducibility of the different supported phases as well as of the supports, and the observed redu-

* Aromatics Technology Division, ESSO Chemie B.V., Rotterdam, The Netherlands.

'University of Amsterdam, Institute for Chemical Technology, Plantage Muidergracht 30, 1018 TV Amsterdam, The Netherlands.

'Prins Maurits Laboratories, National Defence Research Organization TNO, 2280 AA Rijswijk, The Netherlands.

'Eindhoven University of Technology, Department of Chemical Engineering, $5600 \mathrm{MB}$ Eindhoven, The Netherlands. cibilities might be related directly to catalytic oxidation reactions.

In this study, besides Raman spectroscopy and TPR, $\mathrm{X}$-ray diffraction (XRD) and X-ray fluorescence were used to determine crystallite size and vanadium content, respectively. Table I summarizes the catalyst systems prepared in this study.

Two types of catalysts were studied. The first type was prepared by wet impregnation of $\gamma-\mathrm{Al}_{2} \mathrm{O}_{3}, \mathrm{SiO}_{2}$, and $\mathrm{TiO}_{2}$. The second type was prepared by adsorption of polymeric and/or monomeric vanadate ions from aqueous solution on the carriers. ${ }^{1,2}$ In this process anionic exchange of these ions with the surface hydroxyl groups of the carrier oxides $\left(\gamma-\mathrm{Al}_{2} \mathrm{O}_{3}, \mathrm{CeO}_{2}, \mathrm{Cr}_{2} \mathrm{O}_{3}, \mathrm{SiO}_{2}, \mathrm{TiO}_{2}\right.$, and $\left.\mathrm{ZrO}_{2}\right)$ plays an important role as shown by the $\mathrm{pH}$ change of the eluate. ${ }^{1}$ The thermal stability of the latter type of catalysts was studied by Raman spectroscopy after heat treatment to $1073 \mathrm{~K}$ in oxygen flow for $2 \mathrm{~h}$.

Results of this study will be used in the near future in correlating the structural aspects with catalytic behavior in $\mathrm{CO}$ oxidation and other oxidation reactions.

\section{Experimental Section}

Materials. $\gamma-\mathrm{Al}_{2} \mathrm{O}_{3}, \mathrm{SiO}_{2}$, and $\mathrm{TiO}_{2}$ were obtained from Degussa; $\mathrm{CeO}_{2}, \mathrm{Cr}_{2} \mathrm{O}_{3}$, and $\mathrm{ZrO}_{2}$ were prepared as described by Fransen et al.

The $\mathrm{V}_{2} \mathrm{O}_{5}$ used was a Baker product (analytical grade). Ammonium metavanadate (Merck, analytical grade) was used for wet impregnation of the carrier materials. $\mathrm{ZrV}_{2} \mathrm{O}_{7}$ and $\mathrm{CeVO}_{4}$ used as reference compounds in structural analysis were prepared as follows. $\mathrm{ZrO}_{2}$ and $\mathrm{CeO}_{2}$ were each mixed in a ball mill with a stoichiometric quantity of $\mathrm{V}_{2} \mathrm{O}_{5}$ and heated at 973 and $673 \mathrm{~K}$, respectively, for 168 h. In order to remove traces of unreacted $\mathrm{V}_{2} \mathrm{O}_{5}$, we treated the samples with an ammonia solution. ${ }^{27} \mathrm{X}$-ray diffraction showed only the diffraction lines of the pure compounds. The composition was checked by X-ray fluorescence.

Catalyst Preparation. Two preparative methods were applied, the first one being a one-step wet impregnation 
TABLE I: Survey of Catalysts

\begin{tabular}{|c|c|c|c|c|c|}
\hline catalyst series & $\begin{array}{l}\text { preparation } \\
\text { method }^{a}\end{array}$ & $\begin{array}{c}\text { range of } \\
\mathrm{V} \text { contents, } \\
\text { wt } \% \mathrm{~V}\end{array}$ & notation in text & $\begin{array}{c}\text { BET surface } \\
\text { area of } \\
\text { carrier, } \\
\mathrm{m}^{2} \mathrm{~g}^{-1}\end{array}$ & $\begin{array}{c}\text { theoretical } \\
\text { surface } \\
\text { coverage, } b, c \\
\text { V atoms } \mathrm{nm}^{-2}\end{array}$ \\
\hline $\mathrm{V}$ oxide $/ \gamma-\mathrm{Al}_{2} \mathrm{O}_{3}$ & i & $\begin{array}{l}0.5-38.3 \\
6.8\end{array}$ & $\begin{array}{l}\mathrm{V}(0.5-38.3) / \mathrm{Al}-\mathrm{w} \\
\mathrm{V}(6.8) \mathrm{Al}-\mathrm{i}\end{array}$ & 78 & $\begin{array}{r}0.8-184.0 \\
11.7\end{array}$ \\
\hline $\mathrm{V}$ oxide $/ \mathrm{CeO}_{2}$ & $\mathrm{i}$ & 5.3 & $\mathrm{~V}(5.3) / \mathrm{Ce}-\mathrm{i}$ & 48 & 14.4 \\
\hline $\mathrm{V}$ oxide $/ \mathrm{Cr}_{2} \mathrm{O}_{3}$ & $\mathrm{i}$ & 0.6 & $\mathrm{~V}(0.6) / \mathrm{Cr}-\mathrm{i}$ & 20 & 3.6 \\
\hline $\mathrm{V}$ oxide $/ \mathrm{SiO}{ }_{2}$ & w & $1.4-39.8$ & $\mathrm{~V}(1.4-39.8) / \mathrm{Si}-\mathrm{w}$ & 300 & $0.6-54.4$ \\
\hline & i & 1.2 & $\mathrm{~V}(1.2) / \mathrm{Si}-\mathrm{i}$ & & 0.5 \\
\hline $\mathrm{V}$ oxide $/ \mathrm{TiO}_{2}$ & $\mathrm{w}$ & $1.4-47.1$ & $\mathrm{~V}(1.4-47.1) / \mathrm{Ti}-\mathrm{w}$ & 45 & $3.8-787$ \\
\hline & $\mathrm{i}$ & 1.7 & $\mathrm{~V}(1.7) / \mathrm{Ti}-\mathrm{i}$ & & 4.6 \\
\hline $\mathrm{V}$ oxide $/ \mathrm{ZrO}_{2}$ & $\mathrm{i}$ & 4.3 & $\mathrm{~V}(4.3) / \mathrm{Zr}-\mathrm{i}$ & 107 & 5.1 \\
\hline
\end{tabular}

${ }^{a} \mathrm{w}=$ wet-impregnated and $\mathrm{i}=$ ion-exchange. ${ }^{b}$ Lower and upper limit of each w series. ${ }^{c}$ In crystalline $\mathrm{V}_{2} \mathrm{O}_{5}$ the $(010)$ face contains $9.7 \mathrm{~V}$ atoms per $\mathrm{nm}^{2}$, corresponding to $0.103 \mathrm{~nm}^{2}$ per $\mathrm{VO}_{2.5}$ unit. ${ }^{9}$

of the supports using aqueous solutions of ammonium metavanadate. In the second one a freshly prepared solution of 1 wt $\% \mathrm{NH}_{4} \mathrm{VO}_{3}$ with $\mathrm{pH} 4$ was passed through a bed of support. For details see elsewhere. ${ }^{1}$

Subsequently the catalysts were dried at $383 \mathrm{~K}(17 \mathrm{~h})$ and calcined at $723 \mathrm{~K}(2 \mathrm{~h})$.

$X$-ray Fluorescence. The vanadium content of each catalyst was determined on a Philips 1410 X-ray spectrometer after a borax fusion pretreatment. ${ }^{28}$

$X$-ray Diffraction. Some catalyst samples (impregnated series on $\gamma-\mathrm{Al}_{2} \mathrm{O}_{3}, \mathrm{SiO}_{2}$, and $\mathrm{TiO}_{2}$ ) were analyzed on a Philips PW 1050-25 vertical diffractometer.

Raman Spectroscopy. Raman spectra were recorded as described previously. ${ }^{2}$

Temperature-Programmed Reduction. Catalyst samples of such a size that they contained $\sim 2 \times 10^{-5} \mathrm{~mol}$ of vanadium were reduced in a quartz tube $(4.5 \mathrm{~mm}$ i.d.) in a dried $\mathrm{H}_{2} / \mathrm{N}_{2}$ gas mixture with 66 vol $\% \mathrm{H}_{2}$.

All samples were pretreated by calcination at $823 \mathrm{~K}$ in dry air for $1 \mathrm{~h}$ and subsequently cooled under vacuum to $473 \mathrm{~K}$. The flow rate of the $\mathrm{H}_{2} / \mathrm{N}_{2}$ gas mixture was $18 \mathrm{~mL}$ (NTP) $\mathrm{min}^{-1}$, while the tubular furnace was linearly heated from 473 to $1330 \mathrm{~K}$ with a heating rate of $5 \mathrm{~K} \mathrm{~min}^{-1}$. If necessary, the furnace was kept isothermally at the final temperature to complete the reduction. In order to check for possible mass transport limitations, we carried out some measurements at a heating rate of $10 \mathrm{~K} \mathrm{~min}^{-1}$. Hydrogen consumptions were determined according to the method described by Jenkins et al. ${ }^{23}$ Calibration of the TPR apparatus enabled a quantitative thermoanalytical determination of the different phases.

\section{Results and Discussion}

Wet-Impregnated Catalysts. $\mathrm{V} / \gamma-\mathrm{Al}_{2} \mathrm{O}_{3}$. A Raman study of vanadium $(\mathrm{V})$ oxide $/ \gamma-\mathrm{Al}_{2} \mathrm{O}_{3}$ samples, prepared by wet impregnation, was reported earlier. ${ }^{2}$ It was found that at low coverages two broad Raman bands were present. One band around $970 \mathrm{~cm}^{-1}$ was assigned to a two-dimensional polymeric network of distorted octahedra sharing corners and/or edges and seemed to decrease in intensity from 0.5 to $2.1 \mathrm{wt} \% \mathrm{~V}$ in favor of another band around $830 \mathrm{~cm}^{-1}$. The latter was attributed to isolated $\mathrm{VO}_{4}$ tetrahedra on the surface. At higher concentrations (from $3.7 \% \mathrm{~V}) \mathrm{V}_{2} \mathrm{O}_{5}$ crystallites were observed.

The same phenomena are well reflected by the TPR profiles of the same catalyst series as shown in Figure 1. At low coverages (i.e., up to $2.1 \mathrm{wt} \% \mathrm{~V}$ ) only one peak around $650-700 \mathrm{~K}$ is observed. From $2.1 \mathrm{wt} \% \mathrm{~V}$ to 7.1 wt \% V on the low-temperature side of this peak, a new signal appears, first as an increasing asymmetry and finally as an extra peak or shoulder around $600 \mathrm{~K}$. At increasing $\mathrm{V}$ content these peaks shift toward lower reduction tem-

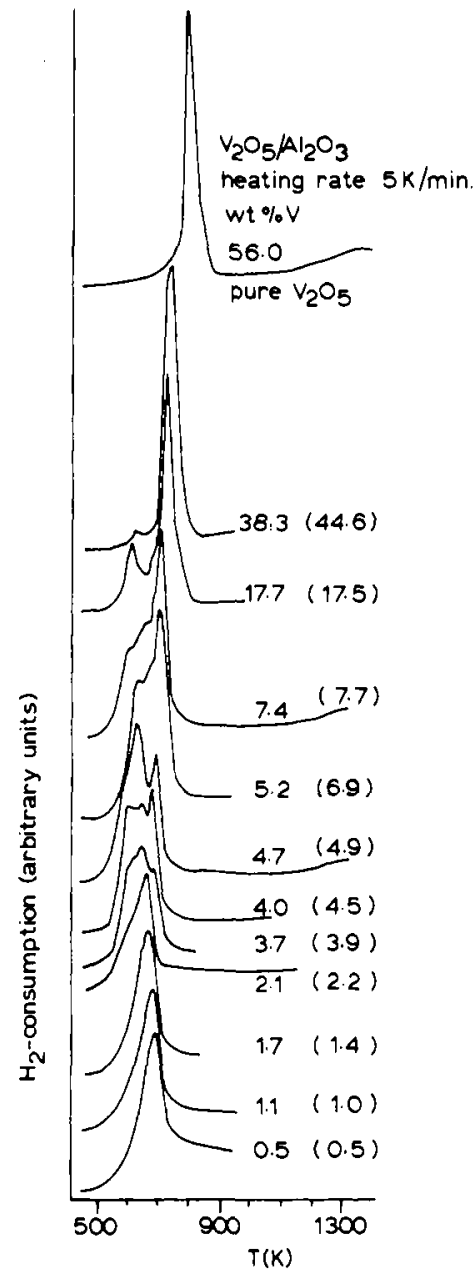

Flgure 1. TPR proflles of impregnated vanadium(V) oxide $/ \gamma-\mathrm{Al}_{2} \mathrm{O}_{3}$ catalysts and of unsupported $\mathrm{V}_{2} \mathrm{O}_{5}$. The $\mathrm{V}$ contents as determined from TPR peak surface areas are given in parentheses.

peratures. Similar, even more pronounced shifts to lower temperatures were reported for alumina-supported molybdenum oxide catalysts which show a shift of the peak due to octahedral surface molybdate from 1150 to as low as $850 \mathrm{~K} .{ }^{25}$ Probably this shift is caused by the heterogeneity of the adsorption sites at the alumina surface and/or the higher degree of polymerization of the species at increasing $\mathrm{V}$ content.

By analogy with a study on alumina-supported molybdena, ${ }^{16}$ one might expect to observe at first isolated vanadate tetrahedra at low surface coverages and an octahedral polyvanadate phase at higher surface coverages. Neither from Raman spectroscopy ${ }^{2}$ nor from TPR (Figure 1) can this be concluded definitely. Both techniques point 


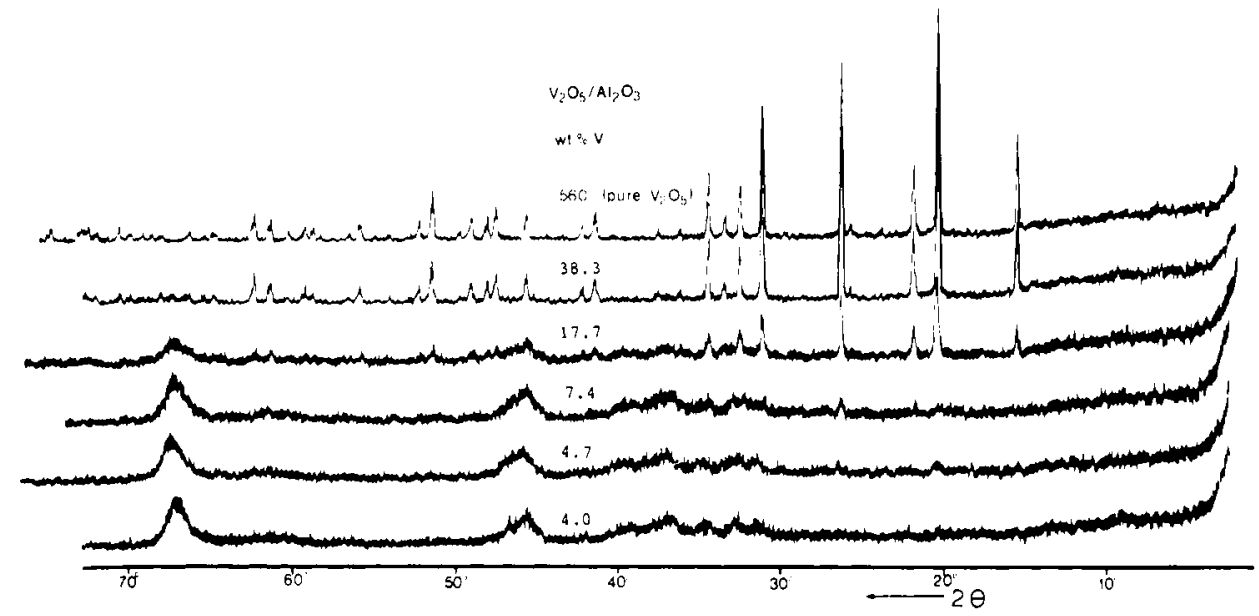

Flgure 2. X-ray diffraction patterns of impregnated vanadium(V) oxide $/ \gamma-\mathrm{Al}_{2} \mathrm{O}_{3}$ catalysts and of supported $\mathrm{V}_{2} \mathrm{O}_{5}$.

to even more polyvanadate octahedra at the lower coverages than vanadate tetrahedra. The dominance of octahedral over tetrahedral coordination seems also present on supported molybdenum and tungsten oxide..$^{16,19,20}$ Moreover this dominance depends on the carrier used and seems to decrease in the order $\mathrm{V}>\mathrm{W}>\mathrm{Mo}$. Apparently for supported molybdenum oxide systems the results are conflicting. Probably the occurrence of tetrahedral molybdate at low coverages depends on the specific characteristics of the carrier used. Further, it cannot be excluded that certain preparation methods as ion exchange and wet impregnation result in a different distribution of the metal ions over tetrahedral and octahedral coordination. ${ }^{29}$

Thus it is likely that octahedral polyvanadate structures are being formed prior to or at least simultaneously with the formation of tetrahedral vanadate species of lower degree of polymerization. A study is in progress to elucidate the nature of the species formed as a result of ion exchange and their possible structural changes on calcination.

From the correspondence with Raman spectroscopy, the TPR peak around $650 \mathrm{~K}$ is assigned to a two-dimensional octahedral polyvanadate surface structure, and the extra peak or shoulder around $600 \mathrm{~K}$ to a tetrahedral vanadate structure.

From 3.7 wt $\% \mathrm{~V}$ a third peak beyond $700 \mathrm{~K}$ is observed coinciding with the appearance of Raman lines due to crystalline $\mathrm{V}_{2} \mathrm{O}_{5}{ }^{2}$ With increasing $\mathrm{V}$ coverage this peak shifts to higher temperatures up to the reduction temperature of pure $\mathrm{V}_{2} \mathrm{O}_{5}$. In order to investigate whether water as a reduction product causes the increase in reduction temperature, we recorded some profiles with a water saturator placed directly before the sample furnace. This caused no shifts in the reduction profiles. It seems more likely that the shift is caused by an increasing $\mathrm{V}_{2} \mathrm{O}_{5}$ crystallite size, reflected by the decreasing XRD line widths (Figure 2). This is in agreement with the findings of Tilley and Hyde. ${ }^{30}$ In a study of the reduction of $\mathrm{V}_{2} \mathrm{O}_{5}$ in an optical microscope, they found that the rate of reduction increases with decreasing crystal dimensions in the crystallographic $c$ direction. It is likely that the relation between rate of reduction and crystal dimension in a certain crystallographic direction holds also for supported systems. This crystallographic direction, however, need not necessarily be the $c$ direction.

Thus crystal size, combined with crystal orientation, may play an important role in reduction behavior. The observation (Figure 1) that unsupported $\mathrm{V}_{2} \mathrm{O}_{5}$ reduces at a higher temperature than alumina-supported crystalline $\mathrm{V}_{2} \mathrm{O}_{5}$ present in $\mathrm{V}(38.3) / \mathrm{Al}-\mathrm{w}$ (with comparable XRD line

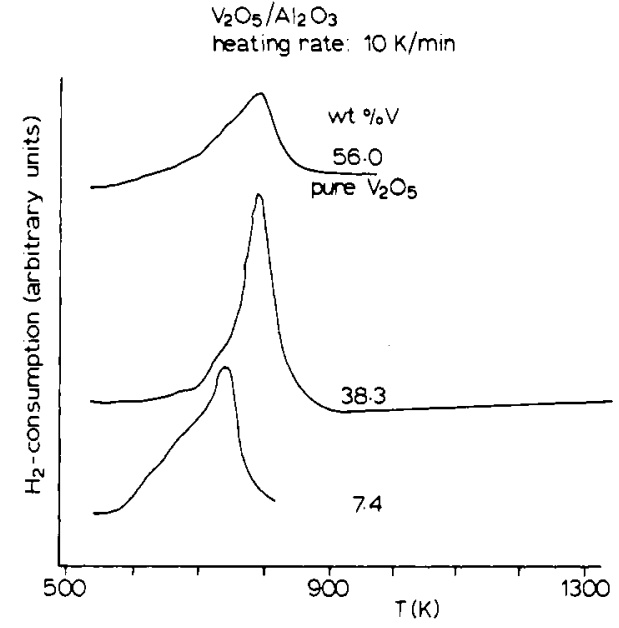

Figure 3. TPR profiles of impregnated vanadium(V) oxide $/ \gamma-\mathrm{Al}_{2} \mathrm{O}_{3}$ and of unsupported $\mathrm{V}_{2} \mathrm{O}_{5}$, recorded at a linear heating rate of $10 \mathrm{~K} \mathrm{~min}^{-1}$.

width, so equal crystal size) supports this idea. Unsupported $\mathrm{V}_{2} \mathrm{O}_{5}$ probably has a random orientation of various crystallographic planes exposed to reduction, whereas supported $\mathrm{V}_{2} \mathrm{O}_{5}$ may display a preferred orientation with better reducibility, for example, (010) $\mathrm{V}_{2} \mathrm{O}_{5}$ lamellae on top of the carrier. 9,31

The difference in reduction behavior is also illustrated by Figure 3: some samples were reduced at a heating rate of $10 \mathrm{~K} \mathrm{~min}$. It is remarkable that the reduction peaks of all samples shift to a higher temperature except for unsupported $\mathrm{V}_{2} \mathrm{O}_{5}$. Although the reasons for these shifts are not yet completely understood, it can be concluded that the high-temperature peak shown in Figure 1 is correctly assigned to $\mathrm{V}_{2} \mathrm{O}_{5}$. The better reducibility of the $\mathrm{V}$. (38.3)/Al-w, compared to unsupported $\mathrm{V}_{2} \mathrm{O}_{5}$ with a comparable crystallite size may be caused by support-induced crystal orientations. Further observations reveal that the vanadium contents, determined from the TPR peak areas, correspond very well with those determined by XRF. (This holds for all vanadia catalysts studied.) The above findings are demonstrated by the data shown in Figure 1. In the calculation it is assumed that the hydrogen consumption is one $\mathrm{H}_{2}$ molecule per $\mathrm{V}$ atom. The agreement with the XRF data confirms that vanadium is, indeed, reduced from pentavalent to trivalent ions.

As mentioned previously ${ }^{2}$ the relative intensities of the Raman bands due to crystalline $\mathrm{V}_{2} \mathrm{O}_{5}$ and to the vanadate surface structures are misleading. Combination of the Raman and TPR peak surface areas shows that in vanadia $/ \gamma-\mathrm{Al}_{2} \mathrm{O}_{3}$ catalysts crystalline $\mathrm{V}_{2} \mathrm{O}_{5}$ is 5-10 time more 


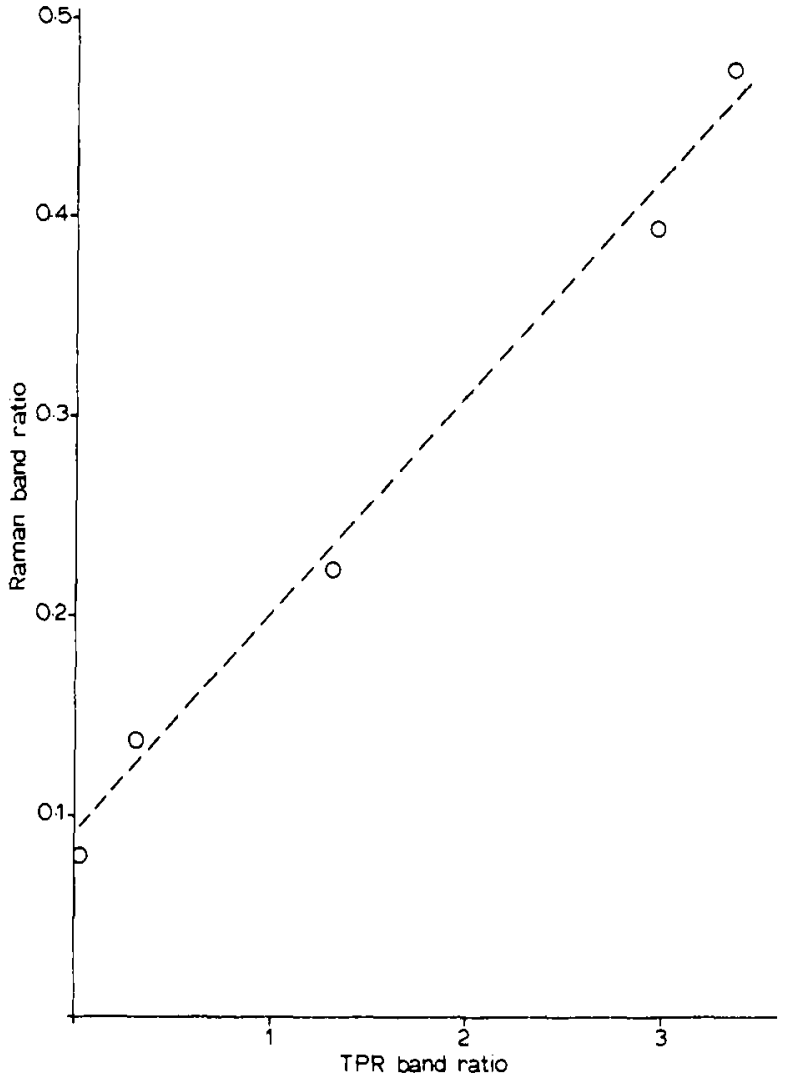

Flgure 4. Relation between Raman intensity ratio and TPR intensity ratio of octahedral and tetrahedral surface vanadate to crystaline $\mathrm{V}_{2} \mathrm{O}_{5}$ for impregnated vanadium(V) oxide $/ \gamma-\mathrm{Al}_{2} \mathrm{O}_{3}$.

Raman active than the surface compounds (see Figure 4).

$\mathrm{V} / \mathrm{SiO}_{2}$. From the TPR profiles presented in Figure 5, similar conclusions are drawn as in the $\mathrm{V} / \gamma-\mathrm{Al}_{2} \mathrm{O}_{3}$ case. Two peaks are observed again, one around $700 \mathrm{~K}$ and another at $700-780 \mathrm{~K}$ which can be assigned to some surface phase (s) and a crystalline $\mathrm{V}_{2} \mathrm{O}_{5}$ phase, respectively. In contrast to $\mathrm{V} / \gamma-\mathrm{Al}_{2} \mathrm{O}_{3}$ catalysts (Figure 1 ), no shifts of the former peak are observed when increasing the surface coverage; this is analogous to silica-supported molybdena. ${ }^{25}$ Figure 7 shows that in XRD the crystalline phase is only observed at coverages exceeding $4.6 \mathrm{wt} \% \mathrm{~V}$, whereas the shoulder on the high-temperature side of the TPR peak recorded for the $\mathrm{V}(2.3) / \mathrm{Si}$-w sample indicates that $\mathrm{V}_{2} \mathrm{O}_{5}$ crystals are also formed at lower coverages.

From the Raman spectrum in Figure 5, it can be seen that, even in the $\mathrm{V}(1.4)$ / $\mathrm{Si}$-w sample, crystalline $\mathrm{V}_{2} \mathrm{O}_{5}$ is present. $\left(\mathrm{V}_{2} \mathrm{O}_{5}\right.$ has Raman bands around $996,703,530$, $483,406,306$, and $285 \mathrm{~cm}^{-1}{ }^{32}$ ) When the $\mathrm{V}$ content is increased, these bands become gradually sharper, indicating that the $\mathrm{V}_{2} \mathrm{O}_{5}$ crystals formed have no well-defined structure up to $4.6 \mathrm{wt} \% \mathrm{~V}$, which is in agreement with the results of XRD analysis in Figure 7.

At first sight the Raman bands around 1020, 900, 830, and $650 \mathrm{~cm}^{-1}$ seem to correspond to the TPR peak around $700 \mathrm{~K}$. It was argued earlier ${ }^{2}$ that the broad band around $830 \mathrm{~cm}^{-1}$, observed at $1.4,2.3$, and 4.6 wt $\% \mathrm{~V}$, can be ascribed to a surface phase with tetrahedrally coordinated vanadium ions. A corresponding TPR peak (expected around $650 \mathrm{~K}$ ) is hardly observable in the profiles of Figure 5. This indicates that only a minor amount of tetrahedrally coordinated $\mathrm{V}$ ions is present. The other bands at 1020 , 900 , and $650 \mathrm{~cm}^{-1}$ are assigned to polymeric arrays of $\mathrm{VO}_{6}$ octahedra. These Raman bands correspond with one single TPR peak at $700 \mathrm{~K}$, indicating that the structure of the octahedral polyvanadate phases does not change significantly when the $\mathrm{V}$ content is increased. a

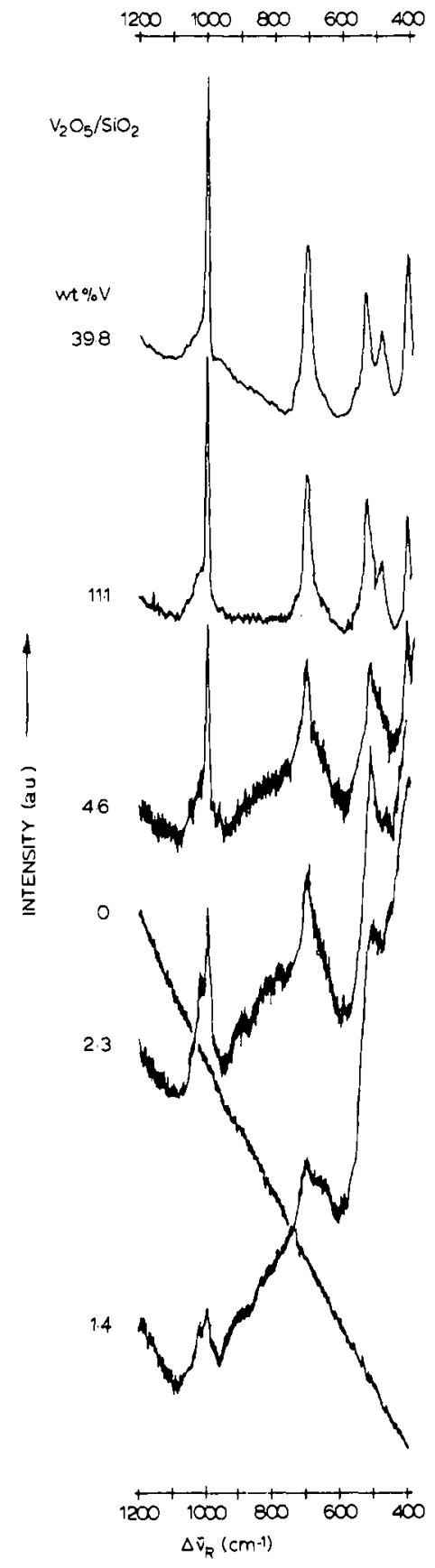

b

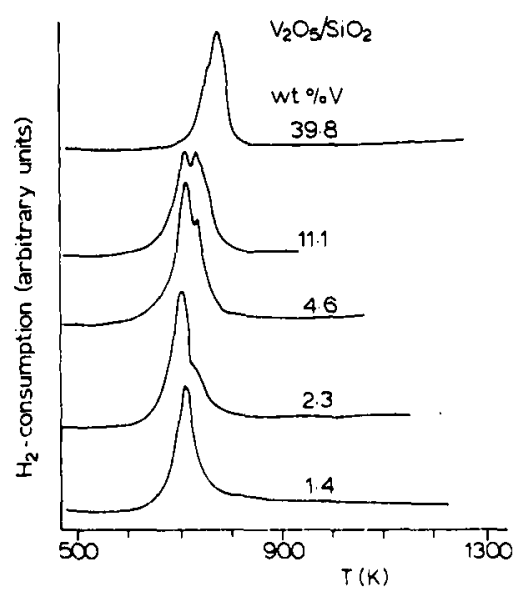

Flgure 5. Raman spectra (a) and TPR profiles (b) of impregnatec vanadium(V) oxide/ $/ \mathrm{SlO}_{2}$ 
$\mathrm{V} / \mathrm{TiO}_{2}$. On titania the situation is comparable. At 4.2 wt \% V crystalline $\mathrm{V}_{2} \mathrm{O}_{5}$ is recorded in TPR (Figure 6) as a peak around $700-750 \mathrm{~K}$, in XRD as small crystallites (Figure 7), and in Raman spectroscopy as sharp lines at 996 and $703 \mathrm{~cm}^{-1} .32$ At lower coverages two TPR peaks are observed at $600-650 \mathrm{~K}$ (or as one peak with a shoulder), corresponding to Raman bands at 980-990 and 920-930 $\mathrm{cm}^{-1}$. It is rather difficult to correlate these Raman bands with the peaks in TPR. Moreover it cannot be concluded whether there is a tetrahedral vanadate phase (band around $830 \mathrm{~cm}^{-1}$ ) because of the presence of an interfering rutile band at $826 \mathrm{~cm}^{-1} \cdot 32$ The other $\mathrm{TiO}_{2}$ Raman bands lie at 612 and $447 \mathrm{~cm}^{-1}$ (rutile) and around 640,515 , and 400 (anatase). ${ }^{32}$ The composition of the titania was determined from its XRD pattern (Figure 7), which yields $65 \%$ anatase and $35 \%$ rutile.

The presence of $\mathrm{TiO}_{2}$ bands in the Raman spectra makes it possible to estimate the penetration depth of the incident laser light. Figure 8 shows the resulting titania bands when the recorded spectra are corrected for vanadium oxide bands and standardized for sensitivity. It is seen that the intensities of the $\mathrm{TiO}_{2}$ bands are reduced by a factor of 6 when the support is covered with $6.3 \mathrm{wt} \% \mathrm{~V}$. From the TPR profile in Figure 6 it follows that at $6.3 \mathrm{wt} \% \mathrm{~V}$ about $50 \%$ of the vanadium oxide is present as $\mathrm{V}_{2} \mathrm{O}_{5}$ crystallites, and $50 \%$ (i.e., $3.15 \mathrm{wt} \% \mathrm{~V}$ ) as a surface phase. The latter phase will be present as a two-dimensional monolayer, as can be calculated from the amount of vanadia involved $(\sim 3.15 \mathrm{wt} \% \mathrm{~V})$ and the BET surface area of $40 \mathrm{~m}^{2} \mathrm{~g}^{-1}$, yielding $10.3 \AA^{2}$ per $\mathrm{V}$ oxide unit. In crystallized $\mathrm{V}_{2} \mathrm{O}_{5}$, which has a lamellar structure, ${ }^{33}$ the calculated surface area per $\mathrm{VO}_{2.5}$ unit in the (010) plane is exactly $10.3 \AA^{29} .^{9}$ Thus, as a model, the $6.3 \mathrm{wt} \% \mathrm{~V}$ consists of $3.15 \mathrm{wt} \% \mathrm{~V}$ as a monolayer array together with an equal amount of vanadia as very small crystallites. This is illustrated schematically in Figure 8.

The V(38.2)/Ti-w sample may thus consist of a monolayer array with a greater number of somewhat larger crystallites than the one supposedly present in V(6.3)/ $\mathrm{Ti}$-w. Here, a major increment in $\mathrm{V}$ content reduced the intensity of the titania spectrum only by a factor of 4 . Thus crystalline $\mathrm{V}_{2} \mathrm{O}_{5}$, when present as small crystallites which do not fully cover the surface, cannot "shield" the underlying outer $\mathrm{TiO}_{2}$ layers. As a consequence the main contribution to "shielding" is performed by the monolayer phase.

When the crystallites grow, the effective shielding of underlying $\mathrm{TiO}_{2}$ layers is increased, especially when they cover the surface to a greater extent. This is demonstrated in Figure 8 in the transition from 38.2 to 47.1 wt \% V. In this case a minor increment in $\mathrm{V}$ content reduces the titania spectrum by a factor of 4 .

In conclusion it may be stated that the scattered laser light intensity is reduced by a factor of $5-6$ after passing through one fully dispersed monolayer with a thickness of $\sim 4 \AA$.

If one compares the characteristic Raman lines of crystalline $\mathrm{V}_{2} \mathrm{O}_{5}$ on silica and titania with the corresponding spectrum of pure $\mathrm{V}_{2} \mathrm{O}_{5}$, the following interesting phenomena can also be observed: although the positions of these lines are the same, their relative intensities are not. Similar effects were found for vanadium oxide on alumina, and a tentative explanation for this was proposed earlier. ${ }^{2}$ A more precise explanation of this observation may be that, because of the presence of small to mediumsized crystallites interacting with the support surface, the selection rules for vibrational transitions are changed, leading to the changes in the intensities. Again crystal form and orientations seem to play a role. a
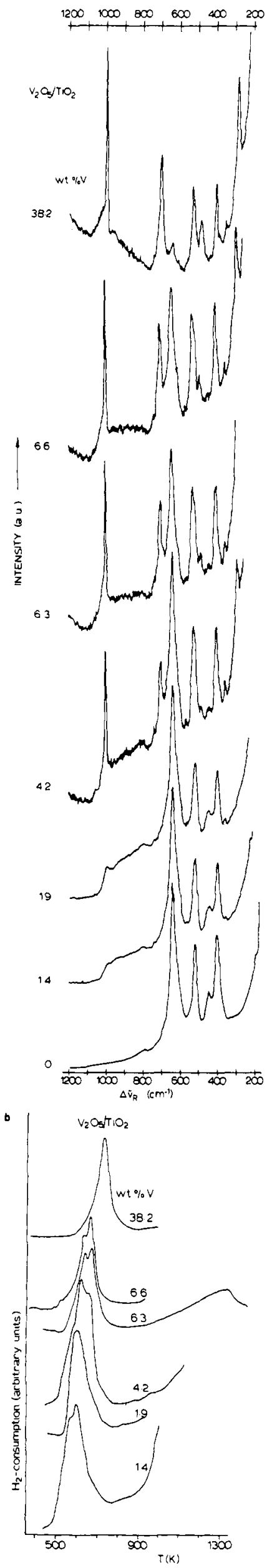

Figure 6. Raman spectra (a) and TPR profles (b) of impregnated vanadium(V) oxide/ $/ \mathrm{TIO}_{2}$. 

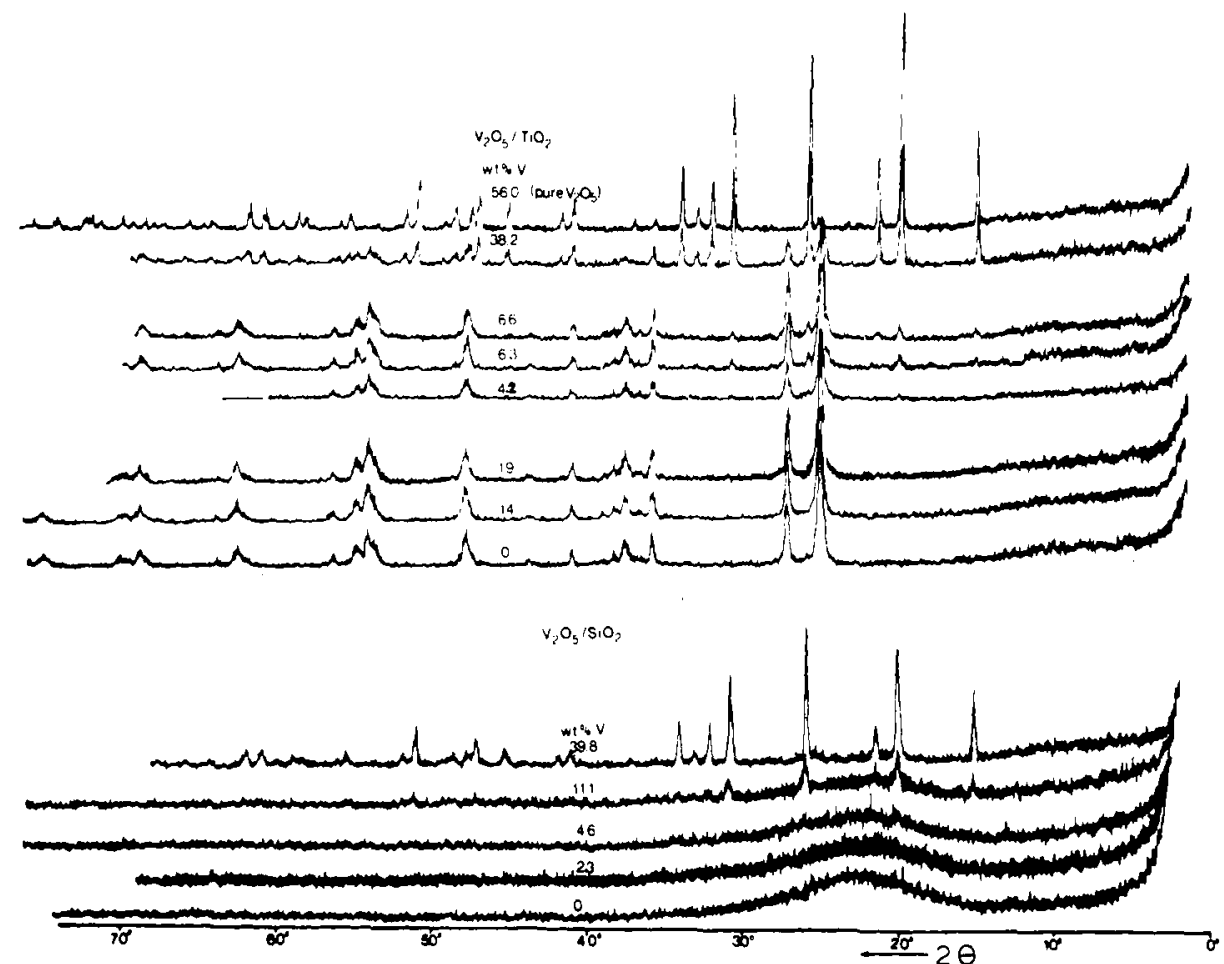

Figure 7. X-ray diffraction patterns of impregnated vanadlum(V) oxide on $\mathrm{SiO}_{2}$ and $\mathrm{TiO}_{2}$ and of unsupported $\mathrm{V}_{2} \mathrm{O}_{5}$.
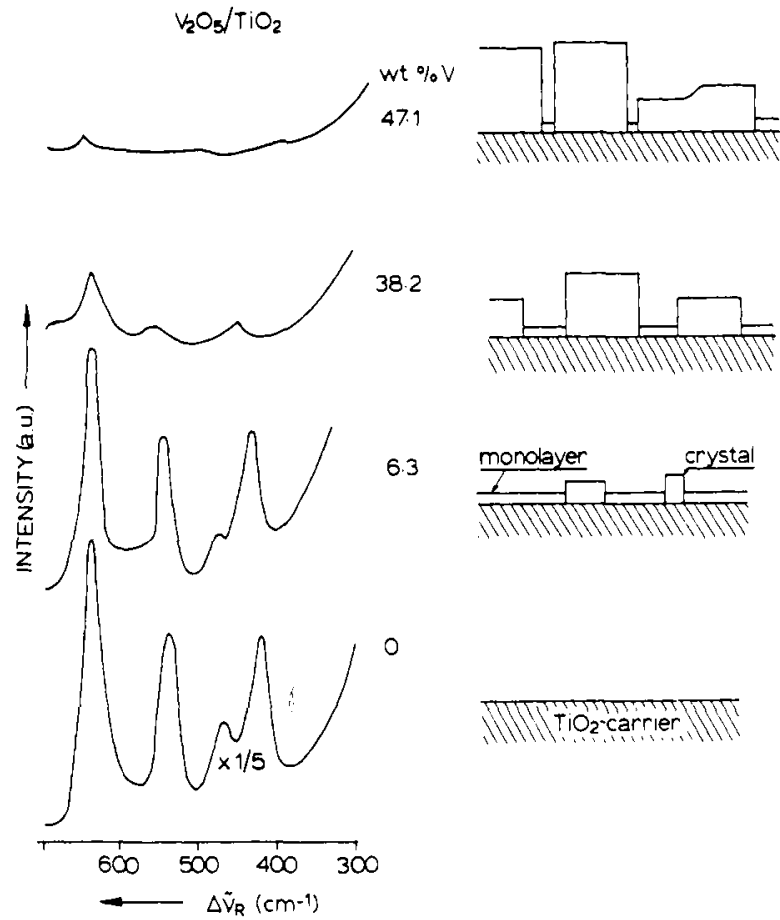

Floure 8. Raman spectra of the $\mathrm{TO}_{2}$ carrier in a series of imoregnated vanadium(V) oxide/TiO $\mathrm{O}_{2}$. Spectra are corrected for vanadium oxide and standardized for sensitivity. The spectrum of pure $\mathrm{TIO}_{2}$ has been scaled down by a factor of 5 .

Ion-Exchanged Catalysts. The TPR profiles of the catalysts, prepared by ion-exchange, ${ }^{1}$ and those of the pure carrier oxides are presented in Figure 9, and Figure 10 shows some corresponding Raman spectra of samples treated at different calcination temperatures $(2 \mathrm{~h}$ in oxygen flow).

$\mathrm{V} / \mathrm{Cr}_{2} \mathrm{O}_{3}$. The TPR profile of vanadia/chromia shows a multiple-step reduction of the chromia at temperatures markedly lower than that of the vanadium oxide. Since this reduction occurs at $650 \mathrm{~K}$, it is concluded that the vanadium oxide is present as a surface phase and not as

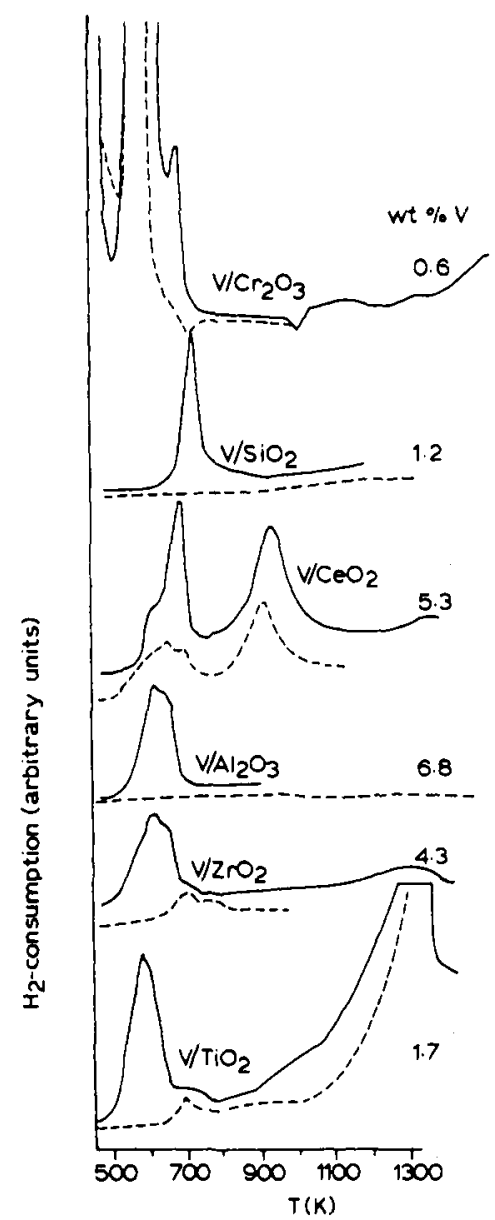

Figure 9. TPR profiles of catalysts, prepared by lon exchange, and of their corresponding supports.

crystalline $\mathrm{V}_{2} \mathrm{O}_{5}$ which reduces above $700 \mathrm{~K}$ for all catalyst systems used in this study. The reduction of vanadium oxide, however, is obscured by that of chromia itself. It is therefore difficult to study the influence of a chromia 


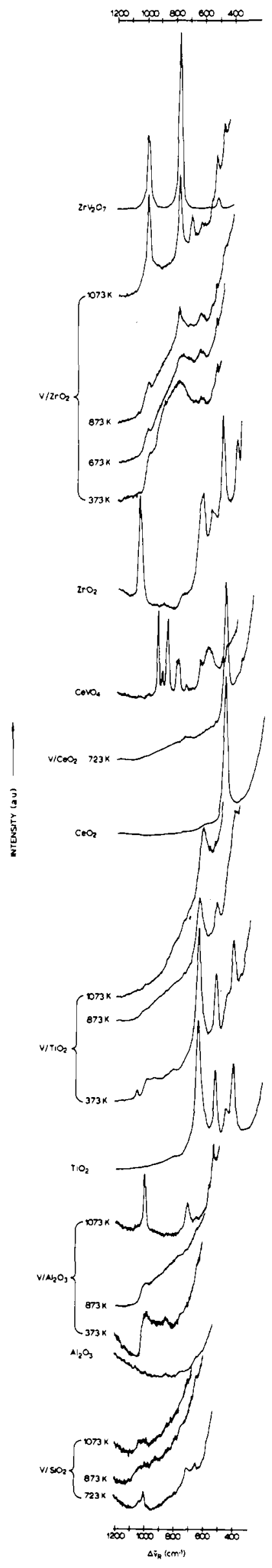

Floure 10. Raman spectra of lon-exchanged catalysts after calcination at different temperatures for $2 \mathrm{~h}$ in oxygen flow. carrier on the catalytic activity of the supported vanadia.

$\mathrm{V} / \mathrm{SiO}_{2}$. The TPR profile and Raman spectrum (723 $\mathrm{K}$ calcination temperature) of vanadia/silica, i.e., V(1.2) $\mathrm{Si}-\mathrm{i}$ are similar to those of the $\mathrm{V}(1.4) / \mathrm{Si}-\mathrm{w}$. Thus, also here a dispersed surface phase is present on the silica together with crystalline $\mathrm{V}_{2} \mathrm{O}_{5}$, reflecting the low affinity between silica and vanadia. This weak affinity was already mentioned previously ${ }^{1}$ where it was shown that on silica the coverage remained far below its theoretical monolayer capacity $(\theta \approx 0.05)$. The influence of the vanadate-silica interaction and the degree of dispersion increase on calcining at higher temperatures (Figure 10). The Raman lines of $\mathrm{V}_{2} \mathrm{O}_{5}$ at 996 and $703 \mathrm{~cm}^{-1}$ disappear while especially the band around $1020 \mathrm{~cm}^{-1}$ increases. The $\mathrm{V}$ content was verified to be 1.2 wt $\% \mathrm{~V}$ before and after calcination. This indicates that no loss of $\mathrm{V}_{2} \mathrm{O}_{5}$ due to sublimation had taken place. Apparently the crystalline $\mathrm{V}_{2} \mathrm{O}_{5}$ with its layer structure depolymerizes at temperatures near its melting point $(943 \mathrm{~K})$. These observations are in agreement with the results of Hanke et al. ${ }^{9}$ and Horvath et al. ${ }^{10}$ It is clear that these thermal effects cannot be studied by TPR, as the reduction is already completed at $800 \mathrm{~K}$.

$\mathrm{V} / \gamma-\mathrm{Al}_{2} \mathrm{O}_{3}$. The TPR profile of $\mathrm{V}(6.8) / \mathrm{Al}-\mathrm{i}$ shows two peaks at exactly the same positions $(600$ and $650 \mathrm{~K}$, respectively) as that of wet-impregnated vanadia/alumina with the same $V$ content. However, now the peak at 700 $\mathrm{K}$ due to crystalline $\mathrm{V}_{2} \mathrm{O}_{5}$ is completely absent, which points to complete monolayer coverage with a tetrahedral and a polymeric octahedral vanadate phase (TPR peaks at 600 and $650 \mathrm{~K}$, respectively). Moreover it shows that our previous assignment of the peak around $700 \mathrm{~K}$ to $\mathrm{V}_{2} \mathrm{O}_{5}$ crystals is correct. Thus, Raman spectroscopy and TPR can be added to the techniques suitable for establishing the presence of a monolayer proposed by Fransen et al..$^{26}$

The thermal behavior of the two surface phases is presented in Figure 10. Drying at $373 \mathrm{~K}$ results in a monolayer phase with bands around $980 \mathrm{~cm}^{-1}$ (octahedral polyvanadate) and $840-850 \mathrm{~cm}^{-1}$ (tetrahedral vanadate). Both bands are present after calcination at $873 \mathrm{~K}(2 \mathrm{~h})$, reflecting the thermal stability of these monolayer species up to this temperature. Heating at $1073 \mathrm{~K}$ results in sharp lines at 996, 703, and $530 \mathrm{~cm}^{-1}$, characteristic for crystalline $\mathrm{V}_{2} \mathrm{O}_{5}$. This is in agreement with the findings of Brandt, ${ }^{34}$ who studied the interaction of vanadia and alumina and found that at $873 \mathrm{~K}$ an interaction compound is formed $\left(\mathrm{AlVO}_{4}\right)$ whereas above $953 \mathrm{~K}$ it decomposes in both oxides.

$\mathrm{V} / \mathrm{TiO}_{2}$. The TPR profile of vanadia/titania, $\mathrm{V}(1.7) /$ $\mathrm{Ti}-\mathrm{i}$, is identical with that of wet-impregnated titania, and the same applies to its Raman spectrum. Bands arising from the presence of some surface phase(s) are observed around $980-990 \mathrm{~cm}^{-1}$ and $920-930 \mathrm{~cm}^{-1}$, and the corresponding TPR peak has a maximum at $600 \mathrm{~K}$. On the vanadia-covered catalyst dried at $373 \mathrm{~K}$ a Raman band is observed around $1050 \mathrm{~cm}^{-1}$ (Figure 10), which is assigned to a $\delta_{\mathrm{OH}^{-}}$vibration mode of hydroxyl groups from the vanadate anions because this is not observed on pure $\mathrm{TiO}_{2}$. This $\delta_{\mathrm{OH}^{-}}$band disappears on further calcination. At 873 and $1073 \mathrm{~K}$ the other two bands around 990 and $930 \mathrm{~cm}^{-1}$ gradually disappear. Moreover the anatase bands (640, 515 , and $400 \mathrm{~cm}^{-1}$ ) decrease in intensity, whereas those of rutile (612 and $447 \mathrm{~cm}^{-1}$ ) increase.

These observations are in agreement with the findings of Vejux and Courtine, ${ }^{31}$ that heat treatment of vanadia/titania (anatase) catalysts above $823 \mathrm{~K}$ leads to the formation of solid solutions of vanadium ions (in reduced $\mathrm{V}^{4+}$ state) in rutile. They suggested both the $\mathrm{V}_{2} \mathrm{O}_{5}$ reduction and the phase transformation from anatase into 
rutile to be topotactic reactions, activated by the remarkable fit of the oxidic crystallographic patterns in contact at the $\mathrm{V}_{2} \mathrm{O}_{5}-\mathrm{TiO}_{2}$ interface. As a consequence, the ease of reduction of vanadia in monolayer contact with a carrier (see Figure 9) may reflect the degree of (mis)fit of the respective structures at the interface, ranging from good on titania $\left(\mathrm{VO}_{2}\right.$ being isostructural with rutile $\mathrm{TiO}_{2}$ ) to poor on silica. Also from catalytic experiments we found evidence for the dissolution of vanadium ions into the $\mathrm{TiO}_{2}$ matrix. ${ }^{36}$

$\mathrm{V} / \mathrm{ZrO}_{2}$. The TPR profiles of vanadia/zirconia and vanadia/alumina are very similar: the same shape and peak positions, indicating that at least two surface phases are present. The Raman spectra of different zirconiasupported catalyst samples are presented in Figure 10. The sharp peak at $1050 \mathrm{~cm}^{-1}$ for pure zirconia points to the presence of a large amount of hydroxyl groups, originating from $\mathrm{ZrO}(\mathrm{OH})_{2}$ which is also formed in the preparation of zirconia. ${ }^{36}$ The disappearance of this peak as a result of vanadate deposition and drying at $373 \mathrm{~K}$ confirms the idea that ion exchange of hydroxyl groups with vanadate species takes place, giving rise to a strong and broad band around $790 \mathrm{~cm}^{-1}$ with a shoulder at 980 $\mathrm{cm}^{-1}$. The "shielding" of the $\mathrm{ZrO}_{2}$ bands reveals that the vanadium oxide is very well dispersed over the surface. The $790 \mathrm{~cm}^{-1}$ band is assigned to a vanadium oxide species with tetrahedral coordination, which may also be rather distorted.

Calcination at $873 \mathrm{~K}$ and higher leads to the disappearance of these two bands and the appearance of bands around $992,780,700,525,470$, and $380 \mathrm{~cm}^{-1}$. The two main peaks (992 and $780 \mathrm{~cm}^{-1}$ ) are also present in the spectrum of $\mathrm{ZrV}_{2} \mathrm{O}_{7}$, as is the minor peak around $525 \mathrm{~cm}^{-1}$. This indicates the formation of $\mathrm{ZrV}_{2} \mathrm{O}_{7}$ phase. The peak at $700 \mathrm{~cm}^{-1}$ may point to a coexisting $\mathrm{V}_{2} \mathrm{O}_{5}$ phase, possibly resulting from thermal decomposition of the $\mathrm{ZrV}_{2} \mathrm{O}_{7}$ into zirconia and vanadia or from formation of a solid solution. ${ }^{37}$

$\mathrm{V} / \mathrm{CeO}_{2}$. When vanadia is supported on ceria, weak Raman scattering between 800 and $1000 \mathrm{~cm}^{-1}$ may point to some vanadium oxide phase which either is incorporated into the ceria lattice or has a much lower Raman activity than cerium oxide, which shows only one band at $468 \mathrm{~cm}^{-1}$. (This is, however, very strong and sharp. ${ }^{31}$ ) There is no indication for the presence of a phase like $\mathrm{CeVO}_{4}$, which has a different spectrum (Figure 10).

Here, TPR gives more information. From Figure 9 it can be seen that the reduction of pure $\mathrm{CeO}_{2}$ takes place in two steps and starts from $500 \mathrm{~K}$. When covered with vanadium oxide this reduction starts at higher temperatures. Also the catalytic activity for $\mathrm{CO}$ oxidation decreases, whereas for all other ion-exchanged catalysts it increases. ${ }^{34}$ The reduction peak at $650 \mathrm{~K}$ on top of these ceria reduction peaks can be assigned to some surface or dissolved vanadia phase(s). It is unlikely that crystalline $\mathrm{V}_{2} \mathrm{O}_{5}$ is among these phases because its TPR peak lies around $700 \mathrm{~K}$

Roozeboom et al. ${ }^{2}$ reported earlier that a dark coloration of the surface vanadate is observed upon irradiation by laser light. In all ion-exchanged catalysts presented in Figure 10 this coloration took place, even when the samples were rotated. Two possible explanations (polymerization and reduction of the vanadate surface species) were discussed in part two of this series. ${ }^{2}$ It is not yet clear whether this is caused by thermal or photochemical effects.

\section{Concluding Remarks}

Crystalline $\mathrm{V}_{2} \mathrm{O}_{5}$ is detected at relatively high $\mathrm{V}$ contents by XRD on $\gamma-\mathrm{Al}_{2} \mathrm{O}_{3^{-}}, \mathrm{SiO}_{2^{-}}$, and $\mathrm{TiO}_{2}$-supported catalysts prepared via wet impregnation. At lower contents it is readily detected by Raman spectroscopy and by TPR, together with some surface vanadate species of two-dimensional character.

$\mathrm{On}$ ion-exchanged catalysts supported on $\gamma-\mathrm{Al}_{2} \mathrm{O}_{3}, \mathrm{CeO}_{2}$, $\mathrm{Cr}_{2} \mathrm{O}_{3}, \mathrm{TiO}_{2}$, and $\mathrm{ZrO}_{2}$, only these monolayer species are detected by Raman spectroscopy as well as by TPR. An exception is $\mathrm{SiO}_{2}$, on which also crystalline $\mathrm{V}_{2} \mathrm{O}_{5}$ is found.

Raman spectroscopy enables only a qualitative analysis of the crystalline $\mathrm{V}_{2} \mathrm{O}_{5}$ and the respective vanadium $(\mathrm{V})$ surface phases. TPR enables a quantitative analysis, provided that Raman bands and TPR peaks can be correlated to each other.

Raman spectroscopy gives valuable additional information about structural changes which occur as a result of heat treatment, e.g., during application in a catalytic process. Thus Raman spectra of ion-exchanged catalyst samples heated at increasing temperatures (373-1073 K) show that monolayer existence is limited and that (1) on $\gamma-\mathrm{Al}_{2} \mathrm{O}_{3}$ the vanadia monolayer structures do not change markedly, (2) on titania a solid solution is formed, (3) on zirconia there is $\mathrm{ZrV}_{2} \mathrm{O}_{7}$ formation, and (4) on ceria apparently small amounts of surface species are present.

TPR also gives information about a catalyst as to its reducibility which can be coupled to its catalytic behavior in reduction-oxidation reactions and to the degree of contact interaction at the interface of vanadia and the respective supports. Better contact seems to enhance the reducibility.

Acknowledgment. Thanks are due to M. Vos (TNORijswijk) for recording the Raman spectra, to Dr. B. Koch (Department of X-ray Spectrometry and Diffractometry, University of Amsterdam) for help in the interpretation of the X-ray diffractograms, recorded by W. Molleman, and to $\mathrm{H}$. T. Weber for performing the X-ray fluorescence analyses. This study was supported by the Netherlands Foundation for Chemical Research (SON) with financial aid from the Netherlands Organization for the Advancement of Pure Research (ZWO).

\section{References and Notes}

(1) F. Roozeboom, T. Fransen, P. Mars, and P. J. Gellings, Z. Anorg. Allg. Chem., 449, 25 (1979)

(2) F. Roozeboom, J. Medema, and P. J. Gellings, Z. Phys. Chem. (Frankfurt am Main), 111, 215 (1978).

(3) P. Mars and D. W. van Krevelen, "Oxidations Carrled Out by Means of Venadium Oxide Catalysts", Spec. Suppl. Chem. Eng., 3, 41 (1954).

(4) W. M. H. Sachtler, Catal. Rev. 4, 27 (1970).

(5) K. Tamara, S. Yoshida, S. Ishida, and H. Kaklota, Bull. Chem. Soc. Jpn., 41, 2840 (1968),

(6) H. Takahashi, M. Shiotani, H. Kobayashi, and J. Sohma, J. Catal., 14, 134 (1969).

(7) S. Yoshida, T. Iguchl, S. Ishida, K. Tamara, Bull. Chem. Soc. Jpn., 45, 376 (1972).

(8) V. A. Shvets and V. B. Kazansky, J. Catal., 25, 123 (1972).

(9) W. Hanke, R. Blenert, and H. G. Jerschkewitz, Z. Anorg. Allg. Chem. 414, 109 (1975)

(10) B. Horvath, J. Geyer, and H. L. Kraus, Z. Anorg. Allg. Chem., 426, 141 (1976).

(11) H. Prallaud and M. V. Mathieu, J. Chim. Phys. Phys.-Chim. Biol., 73, 689 (1976).

(12) V. A. Khalif, E. L. Aptekar', O. V. Krylov, and G. Öhimann, Kinet. Katal., 18, 1055 (1977).

(13) W. Hanke, K. Heise, H. G. Jerschkewitz, G. Kischke, G. ÖhImann and B. Parlitz, $Z$. Anorg. Allg. Chem., 438, 176 (1978).

(14) V. A. Khallf, B. Rozentuller, E. L. Aptekar', K. N. Spiridonov, and O. V. Krylov, KInet. Katal., 19, 1238 (1978).

(15) F. R. Brown, L. E. Makovsky, and K. H. Rhee, J. Catal., 50, 162 (1977).

(16) J. Medema, C. van Stam, V. H. J. de Beer, A. J. A. Konings, and D. C. Konlingsberger, J: Catal., 53, 386 (1978)

(17) H. Knözinger and H. Jeziorowski, J. Phys. Chem., 82, 2002 (1978).

(18) H. Jezlorowskl and H. Knözinger, J. Phys. Chem., 83, 1166 (1979).

(19) R. Thomas, J. A. Moulijn, and F. P. J. M. Kerkhof, Recl. Trav. Chim. Pays-Bas, 96, M134 (1977).

(20) R. Thomas, J. A. Moullin, V. H. J. de Beer, and J. Medema, J. Mol Catal., 8, 161 (1980). 
(21) F. P. J. M. Kerkhof, J. A. Moullin, R. Thomas, and J. C. Oudejans in "Preparation of Catalysts II", B. Delmon, P. Grange, P. Jacobs, and G. Poncelet, Eds., Elsevier, Amsterdam, 1979, 77.

(22) S. D. Robertson, B. D. McNicol, J. H. de Baas, S. G. Kbet, and J. W. Jenkins, J. Catal., 37, 424 (1975).

(23) J. W. Jenkins, B. D. MCNicol, and S. D. Robertson, CHEMTECH, 7, 316 (1977).

(24) V. B. Hughes and B. D. MCNicol, J. Chem. Soc., Faraday Trans. $1,75,2165$ (1979)

(25) R. Thomas, M. C. Mittelmelier-Hazeleger, F. P. J. M. Kerkhof, J. A. Moullin, J. Medema, and V. H. J. de Beer, "Proceedings of the 3rd Intemational Conference on the Chemistry and Uses of Molybdenum", 1979, Ann Arbor, MI.

(26) T. Fransen, P. C. van Berge, and P. Mars in "Preparation of Catalysts I", B. Delmon, P. A. Jacobs, and G. Poncelet, Eds., Elsovier, Amsterdam, 1976, $\mathrm{p} 405$

(27) G. Blasse and J. Hop, J. Solld State Chem., 27, 423 (1979).
(28) J. H. H. G. van Wimgen, H. Kruichof, and E. A. M. F. Dahmen, Talanta, 18, 450 (1971).

(29) A. Iannibello, S. Marengo, F. Triflro, and P. L. Villa in "Preparation of Catalysts II", B. Dolmon, P. Grange, P. Jacobs, and C. Poncolet, Eds., Elsevler, Amsterdam, 1979, p 65.

(30) R. J. D. They and B. G. Hyde, J. Phys. Chem. Solts, 31, 1613 (1970).

(31) A. Vejux and P. Courtine, J. Solld State Chem., 23, 93 (1978).

(32) I. R. Beattle and T. R. Gilson, J. Chem. Soc. A, 2322 (1968)

(33) A. Byström, K. Wilhelmi, and O. Brotzen, Acta Chem. Scand., 4, $1126(1950)$.

(34) K. Brandt, Ark. Keml, 17A, 1 (1943).

(35) F. Roozeboom, A. J. van DHllen, J. W. Geus, and P. J. Gelthings, submitted to Ind. Eng. Chem. Prod. Res. Dev.

(36) H. Th. Rilnten, Thesis, Deltt University of Tectnology, The Nothertands, 1971.

(37) V. M. Fenin, V. A. Shvets, and V. B. Kazansky, Kinet. Katal., 12, 1255 (1971).

\title{
Catalytic OxIdation of Furan on a Mo-TI-O Catalyst. Infrared and Thermodesorption Study
}

\author{
J. Rivasseau, P. Canesson, and M. Blenchard* \\ Laboratolie de Chimie XI, ERA No 371, 86022 Pottiers, France (Recelved: June 11, 1979)
}

The catalytic oxidation of butenes produces maleic anhydride in a multistep reaction, in which furan is one of the intermediates. In order to study the mechanism of this reaction, we have investigated the adsorption of furan on a selective catalyst ( $\mathrm{Ti}-\mathrm{Mo}-\mathrm{O}$ ). Two modes of adsorption were observed, and it appears that the $\mathrm{Mo}=\mathrm{O}$ bond in the catalyst does not play any role in the formation of maleic anhydride.

\section{Introduction}

Among oxidation reactions on heterogeneous catalysts the selective transformation of butene can be of major interest as a substitute of benzene in maleic anhydride production. The reaction mechanism for the oxidation of 1-butene has been extensively studied over, principally, $\mathrm{V}_{2} \mathrm{O}_{5}$ based catalysts; ${ }^{1,2}$ various intermediates, which appear in the gas phase during the reaction, are well identified ${ }^{1,3,4}$ (successively: butadiene, crotonaldehyde, furan, and the final product). Nevertheless the various adsorbed states are ill-defined, and the role of gaseous oxygen is not well understood.

In order to understand what occurs in the adsorbed state, we have studied the adsorption of furan on a Mo$\mathrm{O}_{3}-\mathrm{TiO}_{2}$ catalyst, since it is the last known intermediate product in the oxidation of 1-butene into maleic anhydride. Adsorption was followed at various temperatures by means of infrared spectroscopy and thermogravimetric desorption.

\section{Experimental Section}

Catalyst. The $\mathrm{MoO}_{3}-\mathrm{TiO}_{2}$ catalyst used in this work was the same as that already studied in our laboratory for the catalytic conversion of 1-butene to maleic anhydride. ${ }^{5}$ It was prepared according to the method recommended by Courty et al. ${ }^{6}$ for the synthesis of mixed oxides of known composition. All of the experiments were carried out by using a catalyst containing 15.6 atom \% of molybdenum; its specific surface area was $74 \mathrm{~m}^{2} \mathrm{~g}^{-1}$. Previous experiments have shown that this catalyst is active and selective for the catalytic conversion of 1-butene into maleic anhydride $^{5}$ (53\% maleic anhydride at $60 \%$ conversion).
Before use, the powder was pressed into a wafer $18 \mathrm{~mm}$ in diameter weighing $\sim 50 \mathrm{mg}$ under a pressure of 2 ton $\mathrm{cm}^{-2}$.

Before the adsorption experiments were carried out, the sample of catalyst was oxidized in air for $15 \mathrm{~h}$ at $450^{\circ} \mathrm{C}$, followed by outgassing ( $10^{-5}$ torr) for $1 \mathrm{~h}$ at this temperature and for $2 \mathrm{~h}$ at room temperature.

Products. All of the products used were of commercial origin having a purity better than $98 \%$. They were used after outgassing and drying on a $13 \times$ molecular sieve.

Infrared Studies. A wafer of catalyst was fixed on a support made of titanium foil, allowing a rapid cooling of the sample even under vacuum. This support was introduced into a cell consisting of a $60-\mathrm{cm}$ long cylindrical Pyrex tube equipped with two $\mathrm{KBr}$ windows at one end while the other end allowed thermal treatments. The cell was connected to a vacuum manifold for the various treatments and was transferred to the sample compartment of a Beckman IR 4250 infrared spectrometer for the IR measurements.

Before the spectra were recorded, the cell was evacuated for $15 \mathrm{~min}$ under vacuum of better than $10^{-4}$ torr at room temperature.

Thermogravimetric Measurements. These were made by using a classical Mac Bain system. The catalyst was also used as a wafer which was placed in a small cup hung by a quartz spring the temperature of which was kept constant at $27^{\circ} \mathrm{C}$. The increase in the length of the spring was $1 \mathrm{~mm}$ per $0.83 \mathrm{mg}$, corresponding to $250 \mathrm{~mm}$ on the recorder. Sensitivity was $\sim 0.05 \mathrm{mg}$ for a catalyst mass of $200 \mathrm{mg}$. The cup and the spring were contained in an airtight tube which allowed the various treatments to be 